\title{
An Insight into the Indian Railways COVID-19 Combat
}

\author{
Akhila $\operatorname{Rao}^{1}$ \& Shailashri V. T. ${ }^{2}$ \\ ${ }^{1}$ Research Scholar, College of Management and Commerce, Srinivas University, Mangalore, \\ India \\ OrchidID: 0000-0002-5147-0614, Email ID: Akhilarao87@gmail.com \\ ${ }^{2}$ Research Professor, College of Management and Commerce, Srinivas University, \\ Mangalore, India \\ OrchidID: 0000-0002-1684-238X, Email ID: shailashrivt@gmail.com
}

Area/Section: Business Management.

Type of the Paper: Research Analysis.

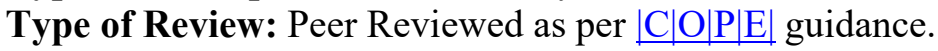

Indexed in: OpenAIRE.

DOI: http://doi.org/10.5281/zenodo.4444381

Google Scholar Citation: $\underline{\text { IJMTS. }}$

\section{How to Cite this Paper:}

Rao, Akhila, \& Shailashri V. T. (2020). An Insight into the Indian Railways COVID-19 Combat. International Journal of Management, Technology, and Social Sciences (IJMTS), 5(2), 389-399. DOI: http://doi.org/10.5281/zenodo.4444381

International Journal of Management, Technology, and Social Sciences (IJMTS) A Refereed International Journal of Srinivas University, India.

(C) With Author.$$
\text { (c) (7) \& }
$$

This work is licensed under a Creative Commons Attribution-Non-Commercial 4.0 International License subject to proper citation to the publication source of the work.

Disclaimer: The scholarly papers as reviewed and published by the Srinivas Publications (S.P.), India are the views and opinions of their respective authors and are not the views or opinions of the SP. The SP disclaims of any harm or loss caused due to the published content to any party.
\end{abstract}




\title{
An Insight into the Indian Railways COVID-19 Combat
}

\author{
Akhila $\operatorname{Rao}^{1}$ \& Shailashri V. T. ${ }^{2}$ \\ ${ }^{1}$ Research Scholar, College of Management and Commerce, Srinivas University, Mangalore, \\ India \\ OrchidID: 0000-0002-5147-0614, Email ID: Akhilarao87@gmail.com \\ ${ }^{2}$ Research Professor, College of Management and Commerce, Srinivas University, \\ Mangalore, India \\ OrchidID: 0000-0002-1684-238X, Email ID: shailashrivt@gmail.com
}

\begin{abstract}
Coronavirus pandemic has affected many lives, and several rigid rules and policies had to be implemented across the globe to curb the spread of the disease. A nation-wide lockdown was announced on March 22, 2020, in India to curb the spread of the Coronavirus (COVID - 19) pandemic. The entire nation was brought to a standstill with only the essential services running. The pandemic had put many of the organizations on the moratorium, especially the travel industry. Indian Railways were no exception to it. But they have risen to the occasion to stand strong with the nation. The efficient disaster management planning of the Indian railways has helped them to fight the battle bravely. Though the passenger trains were brought to a halt in the initial lockdown period, the freight services were functional, carrying out essential duties during the lockdown. From manufacturing and distribution of PPE kits, transportation of essential commodities, service from medical warriors, Indian Railways has taken all the possible steps in the nation's fight against the pandemic. This article focuses on the COVID-19 guidelines followed by the Indian Railways and their noble work during the COVID-19 national crisis for the wellbeing of employees, passengers, and the general public by using secondary data such as journals, newspapers, magazines, and memorandums.
\end{abstract}

Keyword: Indian Railways, COVID-19, Pandemic, Disaster Management, Health, and Safety

\section{INTRODUCTION :}

The SARS-CoV-2 Coronavirus was first identified in the Chinese city of Wuhan and has spread throughout China and the world. The World Health Organization has declared COVID-19 a pandemic. India announced its first case of COVID-19 on January 30, 2020. A nation-wide lockdown was announced on March 22, 2020. Lockdown was carried out in several phases bringing many of the organizations on the moratorium. Some of the facilities, however, were operational, including pharmacies, hospitals, banks, grocery stores, and other vital services to keep life going [1].

Indian Railways, which is considered the nation's lifeline, has once again proved to be at its best in combating the pandemic of Coronavirus. It had briefly suspended its passenger transportation services for the first time in its 167 years of existence to avoid the spread of the virus [2]. However, the pandemic did not halt the IR services. In their battle against the pandemic, the freight services continued alongside some of the significant contributions IR has initiated. They used this time of lockdown to train and educate their personnel to handle the pandemic safely. They conducted several pandemic awareness camps for workers, the general public, and the residents of the Railway colony throughout the country. Many of the offices of the government and non-essential departments were requested to operate remotely. The workers have successfully adapted themselves to these changes. The IR used the existing resources efficiently to manufacture PPE required to protect from COVID-19 in large numbers for their staff and distributed to the public. Several temporary hospitals have been established to treat patients affected by COVID-19. Besides, many developments have been promoted that can aid in the period of crisis, and one of them was the manufacture of low-cost ventilators [3]. At the time of crisis, the IR's freight services transported critical goods across the country. To accommodate growing COVID-19 cases, many of the coaches were converted to isolation wards. This is not the first time IR is facing natural or man-made disasters have been faced by the IR. In the past, there have been many instances, 
such as floods, landslides, and other disasters, where IR played a significant role in helping the country in times of crisis [4][5].

\section{RELATED WORK :}

Table 1: Review of COVID-19 guidelines followed by Indian Railways and its contribution to contain the disease

\begin{tabular}{|c|c|c|c|}
\hline SI No & Area/Topic & Focus & Reference \\
\hline 1 & $\begin{array}{l}\text { COVID-19 and its } \\
\text { impact }\end{array}$ & $\begin{array}{l}\text { Origin and spread of COVID-19 } \\
\text { pandemic. Its impact on travel } \\
\text { Industry. Lockdown implemented } \\
\text { across the country }\end{array}$ & $\begin{array}{l}\text { Tang, X., et al. (2020) [1] } \\
\text { S, V., Advani, M., \& S, P. } \\
(09,2020)[2]\end{array}$ \\
\hline 2 & $\begin{array}{l}\text { Measures to be taken to } \\
\text { curb the spread of the } \\
\text { pandemic }\end{array}$ & $\begin{array}{l}\text { Precautionary measures to be } \\
\text { adapted to prevent the spread pf } \\
\text { Coronavirus. }\end{array}$ & $\begin{array}{l}\text { Xiao, Y., \& Torok, M. E. } \\
(2020) .[3]\end{array}$ \\
\hline 3 & $\begin{array}{l}\text { Contribution of Indian } \\
\text { Railways }\end{array}$ & $\begin{array}{l}\text { The campaign, Manufacturing of } \\
\text { Masks, PPE Kits, low-cost } \\
\text { ventilators, other innovations, } \\
\text { Special trains for essential } \\
\text { commodities transportation, free } \\
\text { meals, Facilities to the employees. }\end{array}$ & S Sen. (2020) [5] \\
\hline 4 & $\begin{array}{l}\text { Services provided by } \\
\text { Indian Railways }\end{array}$ & Shramik special trains & S Sen, (2020) [6] \\
\hline 5 & $\begin{array}{l}\text { Guidelines followed for } \\
\text { suspected and } \\
\text { confirmed COVID-19 } \\
\text { cases }\end{array}$ & $\begin{array}{l}\text { Use of Railway coaches as } \\
\text { COVID Care Centers. Guidelines } \\
\text { followed for the admission and } \\
\text { treatment of Suspected and } \\
\text { confirmed COVID cases in the } \\
\text { isolation coaches. }\end{array}$ & MoFHW, (2020) [7] \\
\hline 6 & Passenger guidelines & $\begin{array}{l}\text { Mandatory requirements to be met } \\
\text { by the passengers for train travel }\end{array}$ & Dutta, A. (2020). [9] \\
\hline 7 & $\begin{array}{l}\text { Preventive measures to } \\
\text { contain spread of } \\
\text { COVID-19 in Railway } \\
\text { workplace }\end{array}$ & $\begin{array}{l}\text { (i) Only essential services to } \\
\text { function. } \\
\text { (ii) Employees to Work from } \\
\text { home on a scheduled basis. } \\
\text { (iii) Keep minimum staffing at } \\
\text { offices. }\end{array}$ & $\begin{array}{l}\text { Janakiraman, S., (2020). } \\
{[10]}\end{array}$ \\
\hline 8 & Awareness campaign & $\begin{array}{l}\text { Spreading awareness of COVID- } \\
19 \text { to the public through posters, } \\
\text { social media, TV news etc. } \\
\text { Conducting awareness campaigns }\end{array}$ & $\begin{array}{l}\text { Sarin, A., \& Sarin, A. } \\
(2020) .[11]\end{array}$ \\
\hline 9 & $\begin{array}{l}\text { Medical services } \\
\text { provided by Indian } \\
\text { Railways }\end{array}$ & $\begin{array}{l}\text { Indian Railway Hospital and } \\
\text { Medical services provided during } \\
\text { the COVID- } 19 \text { pandemic by the } \\
\text { railway doctors and paramedical } \\
\text { team. Mobile COVID testing and } \\
\text { consultation booths }\end{array}$ & $\begin{array}{l}\text { Patel, C. K., et al. (2020) } \\
{[16]}\end{array}$ \\
\hline 10 & $\begin{array}{l}\text { Changes implemented } \\
\text { to adapt to ongoing } \\
\text { pandemic }\end{array}$ & $\begin{array}{l}\text { Contactless } \quad \text { Ticket } \\
\text { system implemented }\end{array}$ & Saxena S, (2020) [13] \\
\hline 11 & $\begin{array}{l}\text { Transportation of } \\
\text { agriculture goods across } \\
\text { the country including } \\
\text { dairy products }\end{array}$ & $\begin{array}{l}\text { Special trains were scheduled to } \\
\text { transport essential agriculture } \\
\text { products and milk across the } \\
\text { country. }\end{array}$ & $\begin{array}{l}\text { Sudha, N., \& Shree, S. } \\
\text { (2020). [20] }\end{array}$ \\
\hline
\end{tabular}




\begin{tabular}{|l|l|l|l|}
\hline 12 & Shramik Trains & $\begin{array}{l}\text { Special trains were scheduled for } \\
\text { migration of laborers who were } \\
\text { stranded during lockdown }\end{array}$ & Khanna, A. (2020). [22] \\
\hline 13 & $\begin{array}{l}\text { ABCD Analysis } \\
\text { framework }\end{array}$ & $\begin{array}{l}\text { ABCD - Advantages, Benefits, } \\
\text { Constraints and Disadvantages. } \\
\text { The analysis method can be } \\
\text { applied for any industry analysis }\end{array}$ & $\begin{array}{l}\text { Aithal, P. S., Shailashree, } \\
\text { V. T. \& Suresh Kumar, P. } \\
\text { M. (2017) [24] }\end{array}$ \\
\hline
\end{tabular}

\section{OBJECTIVES :}

This paper mainly focuses on identifying the Indian Railway's contribution to fighting the Coronavirus pandemic. The main objective of the research paper are as follows:

(1) To explore Indian Railways guidelines during the COVID-19 pandemic.

(2) To identify the contribution of Indian Railways during the COVID-19 pandemic.

(3) Identifying initiatives taken by Indian Railways for the wellbeing and maintenance of employees. The article highlights some of the steps taken by the Indian Railways for the wellbeing of their passengers and the employees during the COVID-19 pandemic such as awareness camps, distribution of PPE, inhouse manufacturing of essentials for COVID-19 precautions, medical aid, etc.

\section{METHODOLOGY :}

The paper consists of conclusions deduced through $\mathrm{ABCD}$ ( $\mathrm{ABCD}$ analysis results in an organized list of advantages, benefits, constraints, and disadvantages in a systematic matrix) analysis of Indian railways dealing with the COVID-19 pandemic which is based on secondary data from varying databases like peer -reviewed journals, reports, magazines, news websites, circulars, and books.

\section{INDIAN RAILWAYS GUIDELINES DURING THE COVID-19 PANDEMIC :}

From March 25, 2020, in the midst of the national lockdown to tackle the spread of the COVID-19 pandemic, the Indian Railways suspended all its passenger, mail, and express trains and began operating the Shramik Special train from May 1, 2020 to transport stranded migrant laborers and others. However, the freight trains were continuing to provide its service to meet the transportation of essential goods throughout the country. In line with WHO COVID-19 protection guidelines, many precautionary steps have been introduced phase-wise [6].

\subsection{Management of suspect/confirmed COVID-19 cases:}

The guidelines for the management of COVID-19 cases in the Railway Coaches- COVID Care Center was issued on $7^{\text {th }}$ April 2020 [7]. As per the guidance document, the Railway coaches were used as COVID Care Centers for the very mild and mild, suspected/confirmed COVID-19 cases. People were screened for the symptoms and clinical conditions and accordingly assigned to the coaches. In case of moderate or severe symptoms, they were referred to the designated centers or hospitals for further management. Standard treatment protocols of the ministry were followed by the trained doctors and paramedical staff deployed to the special coaches for management of cases. Railway Protection Force (RPF) were deployed to monitor the security of the coaches, patients, and staff. Food was arranged by the IRCTC. Proper signages were placed all around the Railway stations. AC temperature of the coaches were controlled. A Basic Life Support Ambulance was also placed in the railway stations. Before handing over the train back for normal use, these coaches should be disinfected and cleared of all biomedical waste. The coaches should be again disinfected regularly by the railways as per the protocol of Ministry of Family and Health until further notice. [7]

\subsection{Guidelines for passengers:}

Passenger trains were gradually started with some criteria being followed like advanced reservation period of 30 days. Reservation Against Cancellation (RAC) was permitted for the passengers. Boarding of train by waiting list passengers and unreserved coaches were cancelled during this period. Ready to eat packed food were provided and other precautionary measures such as social distancing, temperature screening, and hygiene protocols were followed in trains and stations [8]. IR implemented the use of face masks, and Aarogya Setu mandatory for passengers. Also, it was mandatory for the passengers to 
reach the station a minimum of 90 minutes prior to the scheduled train. The AC and Non-AC coaches were modified to make travel safer with new normal requirements [9].

\subsection{Guidelines for Railway employees:}

As a preventive measure for the containment of COVID-19 in the initial phase, several instructions were issued to the Railway employees. All branch offices were asked to prepare a duty roster for employees providing essential services within each department. The offices were kept open with bare minimum staff. Instructions were issued to employees nominated to work from home on a turn basis in the initial phase. They were asked not to leave their city limits without prior approval. They were always instructed not to leave their home during office hours and to be available on telephone or electronic means of communication. All staff were instructed not to venture out to avoid contact with outsiders to safeguard themselves. The offices and surroundings were sanitized regularly. Privilege passes, Privilege Ticket Orders (PTOs), and post-retirement passes were suspended briefly [10].

\section{INDIAN RAILWAYS CONTRIBUTION TOWARDS COVID-19 PANDEMIC :}

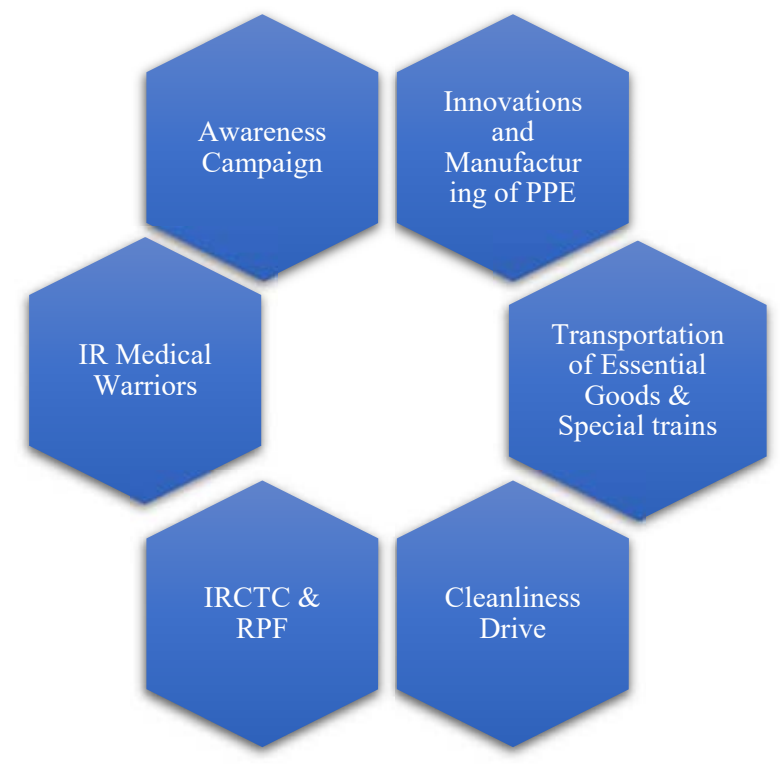

Fig 1: Contribution of Indian Railways towards COVID-19 pandemic

\subsection{COVID-19 awareness campaign:}

The Indian Railways has initiated a Coronavirus awareness campaign for its passengers and employees. Educational Posters, including graphical representations displaying necessary measures to curb the virus's spread, were displayed at prominent locations at the railway stations for passenger information. Regular announcements were made through the public addressing system, health department video clips, and circulated social media messages. Besides, Railway hospital staff, divisional health officers, and other employees conducted awareness campaigns to the passengers, employees, and Railway colony residents. The awareness campaigns helped to reduce panic among the passengers and the employees and educated them on the precautionary measures. The IR has joined the public movement against Covid-19 called the Jan Andolan Campaign -A COVID Acceptable Behavior in the new normal state, which is a COVID protocol awareness campaign such as wearing mask/face cover, maintaining physical distance, etc. Under the 'Break the Chain' campaign some of the initiatives like no curtains, blankets in trains, foot-operated hand wash soap dispensers, social distancing reminders were introduced [5][11].

\subsection{Manufacturing of PPE kits:}

The IR initially procured PPE kits for its utilization. With the growing need for PPE kits, Railways started in house manufacturing of PPE kits. In April 2020, they initially manufactured 1000 PPE kits per day in their 17 workshops spread across the country, which went on to 4000 per day in the 
subsequent month. These PPE kits were not just utilized by the doctors and paramedics of Indian railways but were also supplied to other doctors in the country. The design and quality of these PPE kits were approved by DRDO. Apart from PPE kits which include the apron, gloves, face masks, and face shields, sanitizers were also manufactured in huge quantity. Face masks and sanitizers were supplied to all staff, including contract laborers who were on duty. As of $21^{\text {st }}$ May 2020, 1.2 lakh PPE's, 1.4 lakh liters of sanitizers, and 20 lakh reusable face covers were produced in the workshops of IR $[5][12]$.

\subsection{Manufacturing of ventilators and other innovations:}

The Rail Coach Factory (RCF) trained itself well in advance to combat the deadly Coronavirus and produced many of the crucial pandemic fighting equipment. They began investigating the possibility of having an in-house ventilator, as recommended by the Railway Board, New Delhi.

A low-cost ventilator prototype 'Jeevan' was successfully developed. Most of its components were manufactured in the factory from pre-existing raw materials. Two of its components were outsourced from a company located in Delhi and Noida. Besides this, low-cost commercial-grade sanitizers and foot-operated hand wash dispensers have also been developed by the Rail Coach Factory.

The Southern Railway Signal and Telecommunication Engineers have created a Social Distancing Ensuring Device with a minimal price of Rs. 800 , that alerts social distancing by setting the alarm until the people are 3 meters apart when two or more people wearing the device come within 2 to 3 meters range. A contactless ticket checking system was introduced which works using QR code. Besides, few other innovations have been developed mainly the hands-free amenities, disposable linens, plasma air purifiers in the post-COVID coaches [5][13][14][15].

\subsection{Cleanliness drive:}

To curb the spread of coronavirus infection, the Indian Railways took unprecedented safety steps. Train coaches were sanitized with disinfectants as part of the cleanliness drive to maintain the standards of hygiene, making travel safe for passengers. East Central Railways has issued guidelines for disinfecting the seats, washbasins, toilets, doorknobs, etc. to the sanitation workers of major stations. The Railways have removed the providing of blankets in their AC coaches temporarily. To mark Independence Day, the IR observed a cleanliness week from August 10, 2020. The Ministry of Railways also reported that the critical focus would be the intensive cleanliness of stations, trains, water sales points, toilets, and drains [5].

\subsection{Hospital and Medical services:}

The IR healthcare facilities are distributed all over the 586 health units and 125 Railway hospitals throughout the country. The IR has mobilized more than 2500 doctors and 35000 paramedic personnel to meet COVID-19 needs in a phased manner. All emergency services are continued, and elective surgeries have been deferred temporarily. More than $50 \%$ of the hospital beds were dedicated for treatment of COVID-19 patients. The community centers were turned into quarantine centers, and more physicians and paramedics were hired to manage additional workloads due to increasing COVID-19 cases. Also, a mobile doctor's booth named 'CHARAK' was launched by the national transporter's coach rehabilitation workshop at Bhopal. The portable booth enables zero-contact patient check-ups and guarantees that medical professionals or doctors considering the outbreak of COVID-19 are healthy. Online training for doctors and paramedics were provided. Railway Emergency Cell a 24X7 helpline number for COVID was created as a comprehensive nation-wide unit comprising of around 400 officers and staff. During the lockdown, the cell received queries, requests, and suggestions through their five communication and feedback platforms [16][17].

\subsection{Isolation wards:}

One of the most impressive and innovative innovations of IR is that its 5231 coaches have been transformed into COVID Care Centers by the Ministry of Railways. These coaches were used for mild COVID cases that can be clinically allocated to the COVID Care Centers (CCC) as per the Ministry of health's guidelines. These coaches are adapted to be used in areas where the facilities have been exhausted by the state and need to expand the capacity to separate both suspected and confirmed COVID cases. These coaches served as LEVEL 1 COVID Care Centers, with two beds having oxygen 
cylinder supplies if oxygen supplement is needed. Such healthcare facilities have already been implemented at 85 and IR is ready to extend these services to other stations if needed. A total of 20000 such coaches with 3.2 lakh beds have been identified for conversion in case of requirement [18] [19].

\subsection{Railway Protection Force (RPF) contribution:}

Being the loyal protectors of Indian railways, RPF were deployed to their duties with full PPE at the railway stations. They handled panic/distress calls related to COVID-19 in addition to ensuring and tracking COVID-19 safety measures in the IR stations and offices. RPF provided free food and sanitizers to the poor and vulnerable. They ensured that the RPF control rooms operated smoothly [5].

\subsection{Free meals, temporary essential products market, and other services:}

The Railways Catering and Tourism Corporation Limited (IRCTC) base kitchens across the country in more than 70 locations, distributed free cooked hot food, especially for the stranded people, daily wage laborers, migrants, homeless and poor people. The food was distributed with the help of RPF, GRP, state government commercial department, district administrations, and NGOs. More than 30 lakh free meals were distributed within a month. Water bottles were supplied to police personnel who were on COVID duty.

The Central Railway has permitted the vendors to use its vacant land at Mumbai railway stations for selling fruits and vegetables. The approval was granted immediately by the Government of Maharashtra and the Railway administration. The same model was followed in many other parts of the country to run the temporary markets to supply essentials during the pandemic.

Some of the railway staff have come forward generously lending helping hands to coolie/ luggage porters who have lost their jobs during the lockdown. The team have contributed money on a charity basis, purchased and distributed essential commodities to the needy porters [5].

\subsection{Special Trains:}

When the whole world was on lockdown, Indian Railways were continuing its wheels for the transportation of medical and essential commodities throughout the country with the freight trains which were operational 24X7. Parcel trains were initiated between various destinations. Drone surveillance was introduced in some of the stations to monitor physical movements during the lockdown.

Jai Kisan special freight trains were scheduled for speedy delivery of farm products and food essentials to different parts of the country. In this new concept two trains which mean $84(42+42)$ covered wagons are clubbed together to move as a single train carting 5200 tons of food grains to different destinations [20].

Doodh Duronto special trains which are railway milk tankers were introduced in the national interest to transport milk to different destinations. A single tank could hold up to 42000 liters of milk. The special train reached the destination in 36 hours on par with express trains.

After the lockdown, the main challenge was to ensure proper thermal scanning of the large number of passengers arriving at stations from special trains. Railway officials coordinated with the district administration to arrange appropriate road transportation to transfer the passengers to their native place and vacate the stations [21].

Shramik Special trains: 3840 Shramik special trains were operational since $12^{\text {th }}$ May from various states across the country. Over 52 lakh passengers moved. Free meals and drinking water were provided to the passengers. These trains were specially started for migrant workers and others who were stranded at different places during the lockdown [5] [22].

\subsection{Disinfection chamber:}

A fumigation/disinfection tunnel was set up by Indian Railways at different locations. The fumigation spray starts and sanitizes the entire body of that person when someone enters through it. It can also be used to sanitize pieces of equipment or any items. At Indian Railways' Jagadhri Workshop, a Fumigation Tunnel was set up. A disinfection tunnel at the Electric Loco Shed, Bhusawal, was made available. At the electric loco shed, Kanpur and Jhansi, a total of 3 distinct designs for sanitization tunnel prototypes were prepared [5] [23]. 


\subsection{Rail Tel:}

RailTel Corporation, a Mini Ratna (Category-I) Power Supply Unit under the Ministry of Railways, is one of the country's largest neutral telecommunications infrastructure providers, holding an exclusive Right of Way (ROW) Pan-India optical fiber network along the railway route covering all major cities and towns. RailTel handles crucial communication systems, video conferencing, and e-office platforms as well as storing essential IR data. RailTel has implemented an e-office for IR enabling a paperless office system to work from home using this platform. The users were trained remotely. Most of the meetings took place as video conferencing and video meetings supported by the RailTel HD video conferencing network operation center. Apart from providing essential services, RailTel has contributed Rs 12 crores to Prime Minister Citizen Assistance and Relief in Emergency Situations fund (PM CARES fund) and additionally volunteered Rs. 15.5 Lakh, which is a 1-day salary of all RailTel employees [5].

\section{EMPLOYEE WELL-BEING INITIATIVES OF INDIAN RAILWAYS DURING THE PANDEMIC :}

Awareness campaign: Employees were educated on the dos and don'ts to curb the spread of the COVID19 pandemic. Posters and display boards were put across the Railway stations premises, trains, and other Railway offices and establishments. Dissemination of information related to COVID-19 was done through social media channels. The Railway employees across different zones and divisions took part in the Jan Andolan, a public campaign. Railway officers and staff took the COVID pledge through Video Conferencing.

A collection of steps to be taken by zonal railways to keep employees safe are described in the Rail Parivar Dekh-Rekh Muhim. The procedure to separate its employees from COVID-19 drawn up by the Central Railway is part of the mapping of all its 13-lakh staff and the identification of potential quarantine facilities for each of them. All senior officials concerned were always advised to keep a complete map of the staff with them. They were also told to develop a database of safe staff and volunteers. The protocol notes that the existence of other health conditions such as hypertension and diabetes must be given special consideration to workers and their dependents who have co-morbidities. Each employee has been contacted and mapped wisely so that support can reach them quickly in case of an emergency. In addition, railway employees who collected details such as travel history, the presence of any symptoms of COVID-19 of the employees and their family members were added to a user-friendly web application online survey.

Healthcare services: All central government employees have access to railway health facilities. Half of the beds in the railway hospital were reserved for patients with COVID-19. OPD drug bills could be reimbursed by the staff. Hospital Helpline 24X7 hours was introduced

Mask supply, sanitizers, and PPE kits: Masks and hand sanitizers were distributed to all employees and contract workers. The offices and railway colonies are routinely sanitized.

Safety Counselling: Railway workers are periodically advised about the coronavirus outbreak and are encouraged to download the Arogya Setu App. Mobile train radio communication was used for safe and efficient freight train operations [5].

\section{ABCD ANALYSIS :}

Advantages, Benefits, Constraints and Disadvantages (ABCD) is a model framework used to analyze the effectiveness of a model plan in any organization. In this article we are analyzing the contributions of Indian Railways during the COVID-19 pandemic using the ABCD analysis framework. This analysis will help to understand the constraints of the current system of Indian Railways and can help to develop adequate measures for the smooth transition to new normal [24, 25].

Table 2: ABCD Analysis of the Indian Railways contribution and services provided during the pandemic

\begin{tabular}{|l|l|}
\hline \multicolumn{1}{|c|}{ Factors } & \multicolumn{1}{c|}{ Contents } \\
\hline Advantages & $\begin{array}{l}\text { The Indian Railways has good infrastructure and manpower resources } \\
1 . \quad \begin{array}{l}\text { The medical and healthcare system of Indian railways were geared } \\
\text { up to accommodate the challenges of the pandemic. }\end{array}\end{array}$ \\
\hline
\end{tabular}




\begin{tabular}{|c|c|}
\hline & $\begin{array}{l}\text { 2. Existing Railway infrastructure like Railway coaches, health centers, } \\
\text { etc. are converted into isolation wards } \\
\text { 3. Utilization of Railway factories and workshops for manufacturing } \\
\text { face masks, sanitizers, PPE kits, basic hospital equipment, } \\
\text { disinfection chambers, etc. } \\
\text { 4. Travelers mandated to undergo compulsory thermal screening check } \\
\text { to curb the spread of virus. } \\
\text { 5. Upgraded medical insurance for employees } \\
\text { 6. Indian Railways has always been ahead of others on the IT curve, } \\
\text { being fully online with almost all its freight and passenger activities, } \\
\text { as well as customer support. } \\
\text { 7. With the aid of Anaconda' trains, which are three times the usual } \\
\text { train length, and the launch of 'SETU, a one-stop parcel traffic } \\
\text { helpline to bridge the supply chain gaps, IR has played a key role in } \\
\text { maintaining the supply of essential items such as food grains, dairy } \\
\text { products, and medicines, etc. } \\
\text { 8. Utilization of Railway station areas to sell essential goods to the } \\
\text { public. } \\
\text { 9. Freight loading increased by } 15 \% \text { as of October } 2020 \text { compared to } \\
\text { the previous year. }\end{array}$ \\
\hline Benefits & $\begin{array}{l}\text { 1. Many innovations such as low-cost ventilators, foot-operated soap } \\
\text { dispensers, social distance monitoring equipment were } \\
\text { manufactured to fight the crisis and can be used in future } \\
\text { 2. Zero-base analysis on which passenger segments services should be } \\
\text { retained can be conducted to re-organize the passenger segment } \\
\text { 3. IR can focus on re-modeling the freight business by focusing more } \\
\text { of its resources on goods train } \\
\text { 4. The railways had successfully transported parcels over long } \\
\text { distances through scheduled parcel trains with assured transit time } \\
\text { which can be continued in the future. } \\
\text { 5. Usage of an online platform for both passengers and employees. }\end{array}$ \\
\hline Constraints & $\begin{array}{l}\text { 1. Failure in contact tracing can lead to the spread of the disease and } \\
\text { increases the risk of having second wave in the country. } \\
\text { 2. Higher risk of Indian Railway frontline workers contracting the } \\
\text { disease. } \\
\text { 3. Slowdown in economic growth and reduced revenue. } \\
\text { 4. Breach of lockdown protocols and social distancing norms. }\end{array}$ \\
\hline Disadvantages & $\begin{array}{l}\text { 1. Normal business activity affected especially income generated by } \\
\text { passenger transport } \\
\text { 2. Implementation of rapid changes with minimum staffing on the field } \\
\text { due to lockdown and social distancing rules applied across the } \\
\text { country } \\
\text { 3. Suspension of passenger trains affected the migrant workers, } \\
\text { pilgrims, tourists, and other travelers. } \\
\text { 4. Limited income for the station luggage potters and vendors in and } \\
\text { around the stations. } \\
\text { 5. Limited time and lack of experience to adapt to new working } \\
\text { environment especially remote working culture. }\end{array}$ \\
\hline
\end{tabular}

The $\mathrm{ABCD}$ analysis suggests that there is more advantages and benefits in comparison to constraints and disadvantages in Indian Railways during COVID 19 pandemic which could be positively utilized 
for the development of Indian Railways. This analysis may help to initiate an action plan for developing the Indian Railways economy, revenue, employment opportunities and services [25].

\section{CONCLUSIONS :}

Being one of the pillars of the nation, Indian railways have risen to stand with the country to curb the pandemic. They have provided the much-needed relief materials to the general public all over the nation. The Railways were used extensively during the lockdown period to transport essential goods. Additionally, the Railways manufacturing units came up with several innovations to fight the pandemic and have manufactured right from a few basic hospital furniture like stretchers, beds, medical trolleys to ventilators. The production units also produced consistently PPEs like masks, apron, sanitizers, and face shields for railway employees, doctors, and paramedics across the nation. Based on the guidelines issued by the Ministry of Family Welfare and Health, the IR has successfully trained their staff to work remotely. Their medical insurances were upgraded to accommodate COVID-19 care and were provided with the required medical help during this crisis whenever necessary. The railways proved to be a model organization by its decisive steps taken during the COVID-19 pandemic.

\section{REFERENCES :}

[1] Tang, X., Wu, C., Li, X., Song, Y., Yao, X., Wu, X., Duan, Y., Zhang, H., Wang, Y., Qian, Z., Cui, J., \& Lu, J. (2020). On the origin and continuing evolution of SARS-CoV-2. National Science Review, 7(6), 1012-1023.

[2] Velmurugan, S., Advani, M., \& Padma, S. (2020). Impacts of COVID-19 on the Transport Sector and Measures as Well as Recommendations of Policies and Future Research: Report on India. SSRN Electronic Journal, 1-25.

[3] Xiao, Y., \& Torok, M. E. (2020). Taking the right measures to control COVID-19. The Lancet Infectious Diseases, 20(5), 523-524.

[4] Hu, M., Lin, H., Wang, J., Xu, C., Tatem, A. J., Meng, B., Zhang, X., Liu, Y., Wang, P., Wu, G., Xie, H., \& Lai, S. (2020). Risk of Coronavirus Disease 2019 Transmission in Train Passengers: An Epidemiological and Modeling Study. Clinical Infectious Diseases, Xx, 1-7.

[5] Sen, S. (2020). Indian Railways,64(1),1-81. Retrieved from https://indianrailways.gov.in/HindiMagazine/IRApril2020.pdf. Downloaded on 25/12/2020.

[6] Sen, S. (2020). Indian Railways,64(2),1-68. Retrieved from https://indianrailways.gov.in/HindiMagazine/IRMay2020.pdf. Downloaded on 25/12/2020.

[7] Ministry of Family \& Health Welfare. Director General of Health Services. EMR Division. (2020). Guidance document on appropriate management of suspect/confirmed cases of COVID-19: Railway Coaches - $\quad$ COVID $\quad$ Care $\quad$ Centre. Retrieved from https://cdnbbsr.s3waas.gov.in/s3850af92f8d9903e7a4e0559a98ecc857/uploads/2020/05/2020050 823.pdf. Downloaded on 21/12/2020.

[8] Jain, Y., Midha, K., \& Marwah, S. (2020). How Kerala and Rajasthan Mitigated COVID-19: A Comparative Study. Int J Pharm Pharmacol 2, 2-7.

[9] Dutta, A. (2020). Report 90 minutes in advance and other rules as limited trains start tomorrow. Retrieved from https://www.hindustantimes.com/india-news/report-90-minutes-in-advance-andother-rules-as-limited-trains-start-tomorrow/story-XJcOagLOPaRTkalY6XJ3jK.html. Downloaded on 30/12/2020.

[10] Janakiraman, S. (2020). Guidelines on preventive measures to contain spread of COVID-19 in workplace over Southern Railway. Retrieved from https://sr.indianrailways.gov.in/uploads/files/1590562546323-PBC\%2082\%202020\%20Guidelines $\% 20$ on $\% 20$ Preventive $\% 20$ measures $\% 20$ to $\% 20$ contain $\% 20$ Covid $\% 2019 \% 20$ in\%20workspace.pdf. Downloaded on 06/12/2020.

[11] Sarin, A., \& Sarin, A. (2020). Coronavirus disease (COVID-19): Spread, awareness and strategic containment. Journal of Communicable Diseases, 52(1), 22-31. 
[12] Trivedi, L. C. (2020). Combating COVID-19 pandemic: The role of Indian Railways. Apollo Medicine, 17(3), 235.

[13] Saxena, S. (2020). Amid Covid-19 pandemic, Indian Railways plans to implement QR code-based contactless ticket-checking system. Retrieved from https://www.hindustantimes.com/indianews/amid-covid-19-pandemic-indian-railways-plans-to-implement-qr-code-based-contactlessticket-checking-system/story-xYmixUIbg82Zw27q2iQ1oK.html. Downloaded on 21/12/2020.

[14] Nag, D. (2020). Innovative way to combat COVID-19 spread! Indian Railways' Southern Zone develops social distancing device. Retrieved from https://www.financialexpress.com/infrastructure/railways/innovative-way-to-combat-covid-19spread-indian-railways-southern-zone-develops-social-distancing-device/2019573/. Downloaded on $12 / 12 / 2020$.

[15] Nag, D. (2020). Indian Railways goes innovative in fight against Coronavirus! Check out these top 5 unique initiatives. from https://www.financialexpress.com/infrastructure/railways/indian-railways-goes-innovative-infight-against-coronavirus-check-out-these-top-5-unique-initiatives/1926455/. Downloaded on $12 / 12 / 2020$.

[16] Patel, C. K., Selvam, V. K., \& Sahu, D. K. (2020). Railway anaesthesiologists and Indian railway COVID-19 management system. Indian Journal of Anaesthesia, 64(2), S132-S135.

[17] Malhotra, N., Joshi, M., Datta, R., Bajwa, S., \& Mehdiratta, L. (2020). Indian Society of Anaesthesiologists (ISA National) Advisory and Position Statement regarding COVID-19. Indian Journal of Anaesthesia, 64(4), 259-263.

[18] Sen, S. (2020). Indian Railways, 64(3),1-74. Retrieved from https://indianrailways.gov.in/HindiMagazine/IRJune2020.pdf. Downloaded on 25/12/2020.

[19] Chippagiri, S. (2020). Glory of Indian Railways. Journal of Epidemiology and Community Health, $0(00), 1$.

[20] Sudha, N., \& Shree, S. (2020). One step behind: the government of India and agricultural policy during the Covid-19 lockdown. (Special Issue: The impact of the covid-19 pandemic.). Review of Agrarian Studies, 10(1), 111-127.

[21] Ministry of Health and Family Welfare, Government of India. (2020). Guidelines for domestic travel(air/train/inter-statebustravel). Retrieved from https://www.mohfw.gov.in/pdf/Guidelinesfordomestictravel(airortrainorinter-statebustravel).pdf. Downloaded on 05/12/2020.

[22] Khanna, A. (2020). Impact of Migration of Labour Force due to Global COVID-19 Pandemic with Reference to India. Journal of Health Management, 22(2), 181-191.

[23] Sarada, B. V., Vijay, R., Johnson, R., Rao, T. N., \& Padmanabham, G. (2020). Fight Against COVID-19: ARCI's Technologies for Disinfection. Transactions of the Indian National Academy of Engineering, 5(2), 349-354.

[24] Aithal, P. S., Shailashree, V. T., \& Suresh Kumar, P.M. (2016). ABCD analysis of Stage Model in Higher Education. International Journal of Management, IT and Engineering (IJMIE), 6(1),1124.

[25] Aithal, P. S. (2016). Study on ABCD analysis technique for business models, business strategies, operating concepts \& business systems. International Journal in Management and Social Science, 4(1), 95-115.

[26] Aithal, P. S., Shailashree, V. T. \& Suresh Kumar, P. M. (2017). Application of ABCD Analysis Framework on Private University System in India. International Journal of Management Sciences and Business Research (IJMSBR), 5(4), 159-170. 